\title{
Patent Application in Biotechnology at Subclass C12N in Brazil at the period of 2001 to 2005
}

\author{
Mônica Elisa Buttow ${ }^{1}$ and Mário Steindel ${ }^{1,2^{*}}$ \\ ${ }^{I}$ Programa de Pós-graduação em Biotecnologia;Universidade Federal de Santa Catarina; Rua João Pio Duarte \\ Silva s/n, 88040-970; Florianópolis - SC - Brasil. ${ }^{2}$ Departamento de Microbiologia, Imunologia e Parasitologia; \\ Universidade Federal de Santa Catarina; Rua João Pio Duarte Silva s/n, 88040-970; Florianópolis - SC - Brasil
}

\begin{abstract}
An analysis of Instituto Nacional de Propriedade Industrial (INPI) patent database from 2001 to 2005 showed that less than 5\% of the total patent deposited in the subclass C12N, which referred to "Microorganisms or Enzymes, Compositions thereof, Propagating, Preserving or Maintaining Microorganisms, Mutation or Genetic Engineering, Culture Media", were from national depositors. In contrast, more than $34 \%$ of all these deposits came from the United States of America during the same period. Among the national depositors, public universities and government research institutions contributed with $83 \%$ over all the deposits, demonstrating that research and development in the field of Biotechnology in Brazil has been concentrated within Brazilian public institutions during this period.
\end{abstract}

Key words: Patents, Biotechnology, Intellectual Property, Technologic Innovation

\section{INTRODUCTION}

Advances in the modern biotechnology have improved the quality of human life in recent decades. Through innovative techniques and accumulated knowledge from several generations it has great economic potential. Development of biotechnology requires investment in specialized personnel, as well as, investment in complex research infrastructure. Due to the high economic costs of biotechnology research, knowledge protection plays an essential role in the economy and in development of countries (Buttow 2008; Silva 2007).

Intellectual property rights are considered an incentive for innovation, not only for their marketing, but also for securing the knowledge to enable research progress (Moreira et al. 2006). The role of rights of intellectual property is noteworthy for the development of a country regarding the dissemination of information, the emergence and stimulus of new technologies, and diversification of production. This ensures to inventors and investors the spread of the creation of new goods and services, generating jobs and wealth, and thus contributing to a better quality of life for millions of people (Boff 2007).

Currently, biotechnology research in Brazil is strongly associated with public universities and research institutions. However, issues related to knowledge protection and establishment of productive partnerships with the industry for the development of new technologies are still quite basic (Buttow 2008).

In contrast with the developed countries, where research and development activities are strongly associated with the industry, the majority of research activities in Brazil are concentrated in the

*Author for correspondence: msteindel@gmail.com 
public universities and government research centers, causing the technological innovation process to become more difficult. Companies are the main sector for technological innovation, and the university-industry partnerships possess an essential role in this context (Morel et al. 2007). Therefore, preparation of researchers at the university level to recognize the technological and economic potential of their research is of utmost importance.

Despite the relevant scientific growth in the last decade, demonstrated by increased number of indexed scientific publications, Brazil did not adopt a successful protocol to transform the knowledge into wealth. For example, in 2005, Brazilian universities graduated 10,600 doctorates $(\mathrm{PhD})$, in which the majority of young graduates have been still driven by the academic positions mainly in government-funded universities or research institutes (Buttow 2008). In developed countries, $77 \%$ of the financial support for Science, Technology and Innovation $(\mathrm{S}, \mathrm{T} \& \mathrm{I})$ comes from the private sector, whereas in Brazil, $80 \%$ of all the investments in research and development are from government funding (Gouvêa and Kassicieh 2005).

The Brazilian Industrial Property Law of 1996 was created in accordance with the Trade-related aspects of intellectual property rights (TRIPS). These rules were important, given the different patterns of accumulated technology in each region in order to establish the minimal principles of protection for all signatory countries in an effort to reduce the obstacles for international businesses. For example, in the field of genetics, the participation of Brazilian holders in total deposits held in Brazil did not reach 3\% between 1998 and 2000 when compared with other fields of the C12N subclass (Fortes and Lage 2006).

In Brazil, the university-industry interaction presents several obstacles regarding the infrastructure and investment. Public universities mainly develop basic research for knowledge advances and training of human resources, whereas research in the industry level requires an adaptation into the globalized market (Cruz 2000). By definition, the institutional competence of the university is to produce qualified human resources and development of basic research for the society with no interest in marketing or profit (Brisolla 2007). In contrast, private companies are looking for marketable results and require research confidentiality (Brisolla 2007).
According to Morel et al. (2007), the concept that academia is responsible for basic research development emerged after the Second World War and was inspired by the linear concept of technological development. Basic research has been considered necessary and sufficient to improve the social, economic and technological changes in many developing countries. Whereas many developed countries have quickly improved their industry infrastructure and have become worldwide leaders. This process in Brazil has resulted in a lack or a failure of communication between the academia and industry.

The success of the academia-industry interaction depends on several factors, such as objectives delimitation, management of conflicts of interest and development of a clear definition of intellectual property rights, to ensure the benefit of the partnership for both. If successful, the partnership will prove to be beneficial for the country as a whole.

\section{MATERIALS AND METHODS Patent Database}

In the present study, the International Patent Classification (IPC), which provided access to technical information organized according to the standards established by the Strasbourg Agreement, was used. As proposed by Vasconcellos (2003), Fortes and Lage (2006), and Sapsalis et al. (2006), the subclass $\mathrm{C} 12 \mathrm{~N}$ was chosen to represent the modern biotechnology, which covered the technologies related to "microorganisms or enzymes, compositions thereof, propagating, preservation or microorganism maintenance, mutation or genetic engineering and culture media". Data was compiled using the following parameters: number of applications per year in subclass $\mathrm{C} 12 \mathrm{~N}$, number of applications per year in subclass $\mathrm{C} 12 \mathrm{~N}$ taking into account the main group, i.e., $\mathrm{C} 12 \mathrm{~N} 01,03,05$, $07,09,11$ and 15 , as well as the number of $\mathrm{C} 12 \mathrm{~N}$ applications per country of origin. The profile of the main national applicant of public and private sector, while considering the applicant institution, was also analyzed.

Data from the period $01 / 01 / 2001$ to $31 / 12 / 2008$, was collected from the website of the Brazilian Patent Database of the Instituto Nacional de Propriedade Industrial (INPI) (www.inpi.gov.br), which possessed a database of an estimated 24 million patent documents from several countries 
organized in the form of articles, CD-ROM and an electronic register of patent applications since 1990.

\section{Patent applicants}

For identification of the patent applicant, the patents were identified by the home institution and then categorized into one of the following groups: public university or public research institution, private university or private research institution, public or private companies and individual applicant. When the patent had a co-applicant, the co-applicant was classified in this work as a partnership. When the applicant was an individual(s), the institution origin was determined by searching in the inventor platform or in the curriculum Lattes database. When no institutional affiliation of the patent inventor was found, the patent was considered as individual(s), as proposed by Fortes and Lage (2006).

\section{RESULTS AND DISCUSSION}

\section{Applications of patents in subclass C12N}

Although other classifications also covered the biotechnology area, the subclass C12N classification presented a wider coverage and essentially represented the technological innovations made in the field of modern biotechnology. The approval of the Law $n^{\circ}$. 9279/96, which controlled the rights and obligations concerning industrial property, created significant advances in biotechnology patent deposits in Brazil. Between 2001 and 2005, a total of 1,945 patent applications in the subclass $\mathrm{C} 12 \mathrm{~N}$ were filed at the INPI (Fig. 1). The amount of deposits in this subclass suggested an increasing interest in this branch of technology and also revealed the global importance of the Brazilian market.

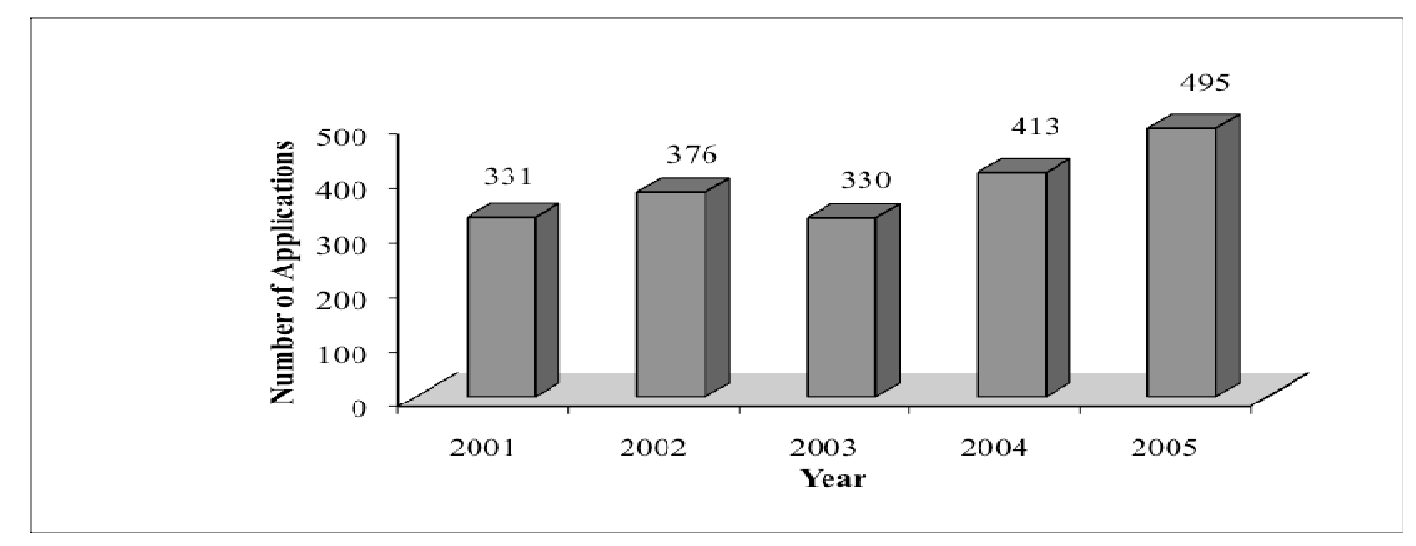

Figure 1 - Total number of patents applications in subclass $\mathrm{C} 12 \mathrm{~N}$ per year in Brazil from 2001 to 2005.

Figure 2 showed that the annual number of patent filings in the $\mathrm{C} 12 \mathrm{~N}$ subclass recorded between 2001 and 2008 displayed a stable number of filings between 2001 and 2003 and a slight increase in the number of applications in 20042005. Surprisingly, a dramatic decrease of patent filings was noted between 2006 and 2008. This low number of registers could be attributed to several factors, such as the required period of secrecy (18-months), the delay in the publication of approved applications due in part to legal bureaucracy and internal operational difficulties at the INPI. It is possible that a significant number of deposits, especially those involving the patent cooperation treaty (PCT), have not yet been published, despite the period of secrecy already being expired. The delay in publication of approved patent deposits may cause an underestimation of the real number of patent deposits, which may also affect the confidence in the INPI database. For this reason, the data analysis presented in this study only included data from the period of 2001 to 2005.

Figure 2 shows a large annual increase in the number of patent filings (32 filings in 1990 to 495 deposits in 2005). One hundred and ninety-four applications were filed in the pipeline mode between 1996 and 1997, which opened the opportunity to patent research results that, up till 2008, were regarded as not patentable in Brazil. 
The majority of these filings were from the United States.

This so-called pipeline protection is a transition instrument that allows for the patenting of inventions that have become public or were filed on the exterior, thus excluding the requirement of novelty (Castilho 2001). The patent pipeline validity begins on the date of filing in Brazil and continues until the end of the remaining term of protection in the country where the first application was filed. However, the limit of this term is twenty years for a regular national patent (Scholze 2001; Barbosa 2002). The same benefit would be conceded to a national or a resident in the country, provided that its object was not placed on any market by direct initiative of the holder or by third parties with consent. The patent, if warranted, would be valid for 20 years from the date of invention disclosure.

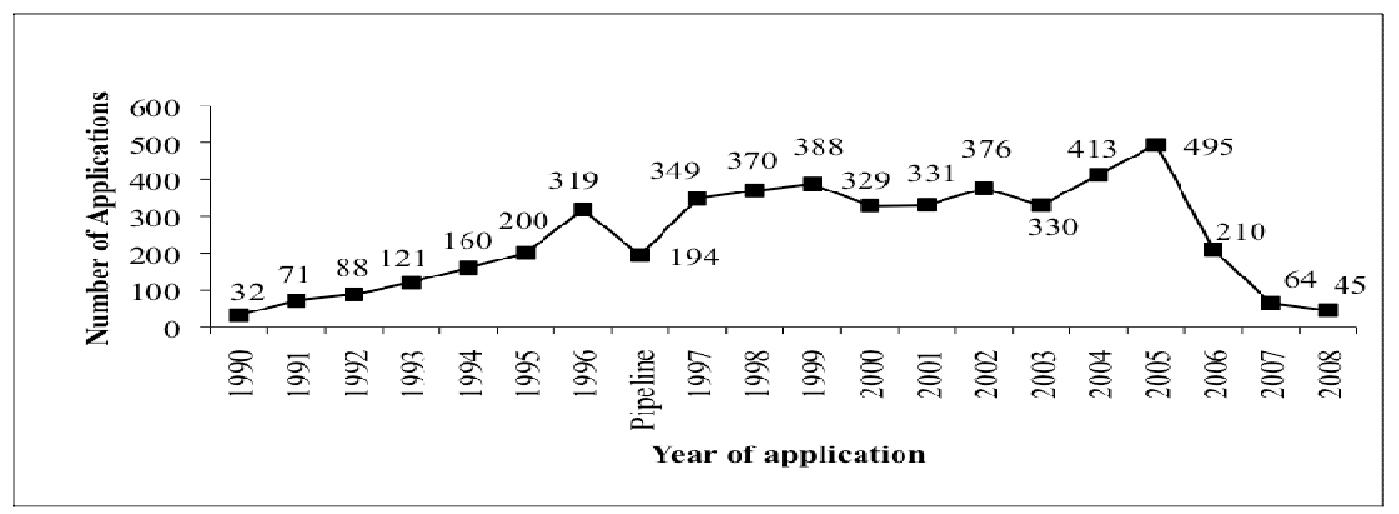

Figure 2 - Total number of patents applications in subclass C12N in Brazil from 1990 to 2008 at the INPI database.

An analysis of the patent filings in the subclass C12N between 2001 to 2005 by country origin, revealed that of the 1,945 applications, $34.6 \%$ were from the United States of America, 9.3\% from Germany, $7.6 \%$ from Japan, $4.8 \%$ from Brazil, and $4.7 \%$ from China (Fig. 3). The Brazilian contribution year-wise was $2.7 \%$ in
$2001,3.7 \%$ in $2002,7.5 \%$ in $2003,5.5 \%$ in 2004 and $5.4 \%$ in 2005 . The dominance of developed countries on technology appropriation in this area showed an enormous quantity of money was being spent by Brazil on licenses, since these patents would remain in force in the country for a period of 20 years.
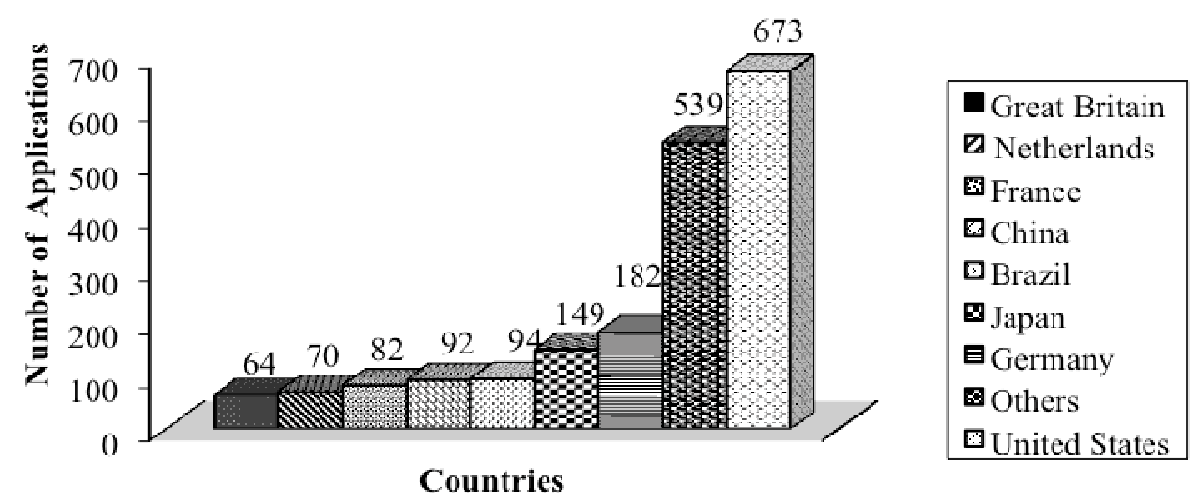

Countries

Figure 3 - Number of patent applications in subclass C12N in Brazil by country origin in the period from 2001 to 2005 . 
The status of technological innovation in a country can be measured based on the number of patent deposits. Although Brazil contains highly qualified human resources in scientific and technological development, which are still working at the academic level, the lack of guidelines and politics causes difficulty for the improvement of strategies for investment in technological innovation by Brazilian companies (Vasconcellos 2003). For biotechnological innovation, it is essential that qualified researchers are working in industry, rather than academia, in order to change the outlook of Brazilian researchers in the field of life sciences (Vasconcellos 2003).

Although Brazil possesses advanced technology research in many areas and contains the greatest biodiversity on the planet, lack of knowledge protection causes the information developed there to be easily available for foreign countries. The initial use of the patent system by the national inventors revealed by the low number of patent requests in the field of biotechnology contributes to the increase in asymmetry between developing and developed countries (Moreira et al. 2006).

According to Morel et al. (2007), since the 1990's, Brazil has experienced an increase in the number of published articles, as well as, patent applications at the USPTO (United States Patent and Trademark Office). However, the ratio between the patent applications and research papers remained low, suggesting that not enough research was being translated into real products (Bernardes and da Motta e Albuquerque 2003).
From the 94 Brazilian patent applications in subclass $\mathrm{C} 12 \mathrm{~N}$ between 2001 and 2005, 83\% came from public universities or public research institutes. Considering all the deposits made in the INPI during this period, the Brazilian patents represented only $4 \%$. The major Brazilian public institutions with patent applications in subclass C12N, between 2001 and 2005 are shown in Figure 4. No application from the private universities during this period was found, demonstrating that the biotechnological research and innovation in Brazil is generally developed in public universities or research institutes.

The analysis of the patent deposits distribution by the groups of subclass $\mathrm{C} 12 \mathrm{~N}$ showed that the majority of deposits belonged to the $\mathrm{C} 12 \mathrm{~N} 15$ group, which was the subclass related to mutation or genetic engineering process. This majority demonstrated the importance of genomic technologies in the field of biotechnology.

Of the total number of national applicants between 2001 and 2005 at the subclass C12N, 55 were from the universities or research institutions, 27 were made in partnership, eight were from private companies, two were made by individuals and two were from supporting agencies (Fig. 5).

An analysis of the partnership profile of patent applicants filed in Brazil in the period 2001 to 2005 is shown in Figure 6. The high level of partnerships between the public universities and/or research institutes revealed that the interaction between the public research centers and companies was still in its initial stages in Brazil.

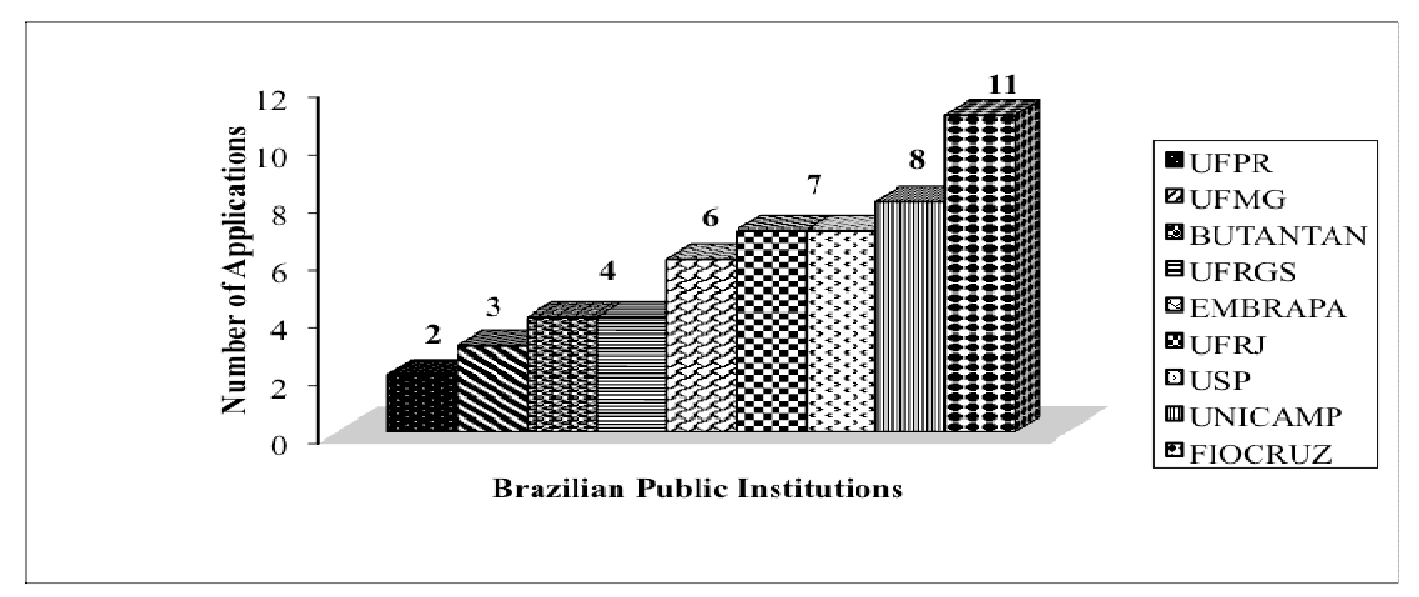

Figure 4 - Number of patent applications in subclass C12N in Brazil, among the Brazilian Public Institutions, in the period from 2001 to 2005. 


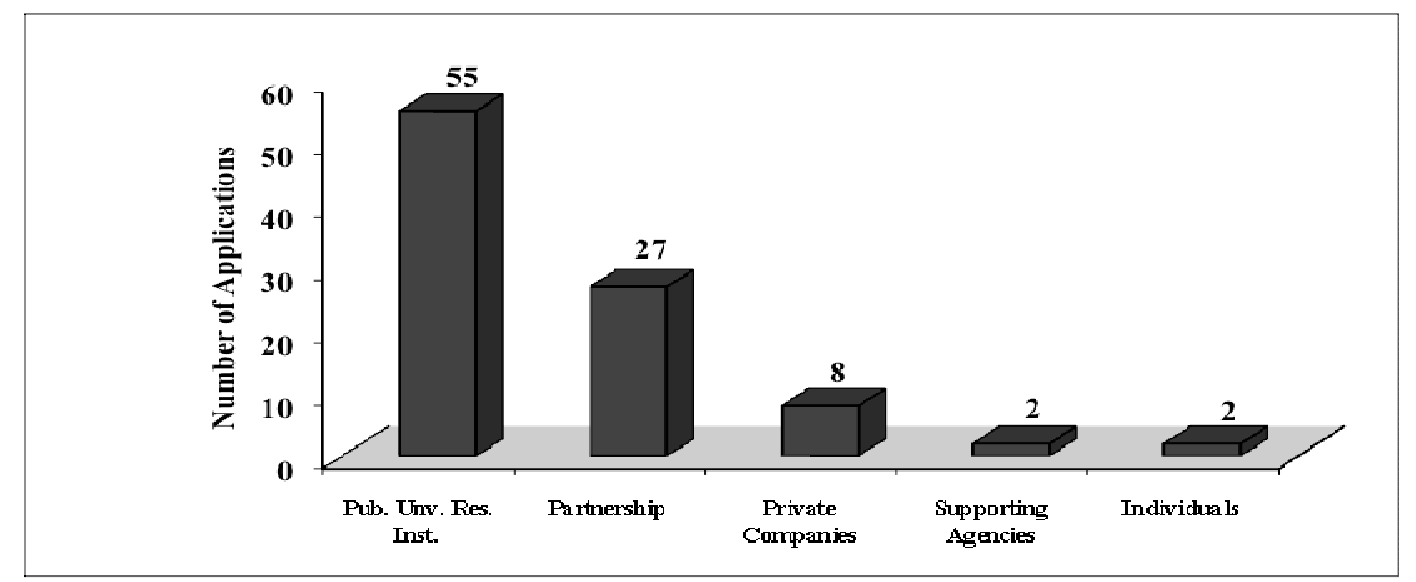

Figure 5 - Number of Brazilian patent applications by profile of applicants in the period from 2001 to 2005.

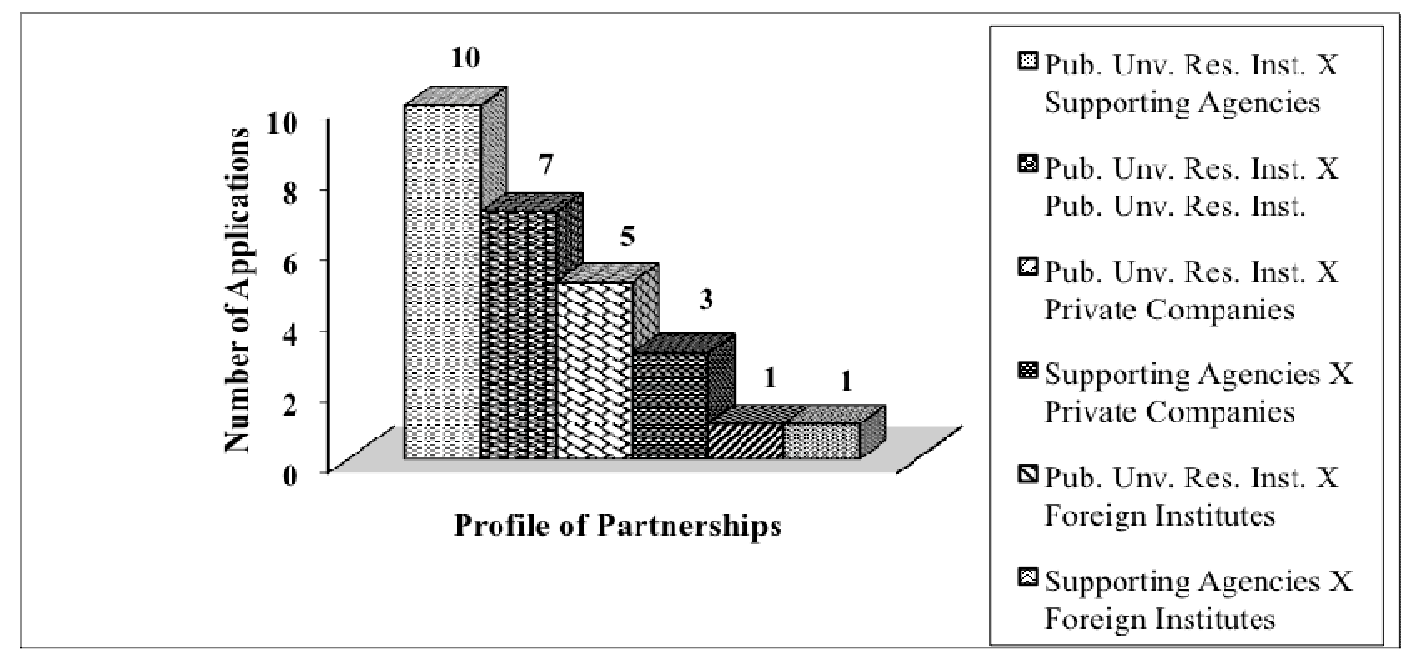

Figure 6 - Profile of partnerships applicants in Brazil in the period from 2001 to 2005.

Although the number of partnerships between the academic institutions and companies increased, these relationships were still largely deficient in dealing with the patenting and technical management bureaucracy between the public and private sector (Emerick 2001). It is imperative for the Centers of Technological Innovation (NITs) of the universities to provide the interaction with the companies and government agencies to develop strategic partnerships of common interest in seeking licensing opportunities that encourage research activities in technology. The facility of Science and Technology Institutes (STI) to license their technologies, the possibility of small and medium companies to use public research facilities, the authorization for researchers linked to STI to develop research in a private company, and the possibility of distribution of earnings between the parties, including the researcher, are among some the benefits of such partnerships (Gulo and Guerrante 2006).

According Sapsalis et al. (2006), there was a significant increase in patents generated in Belgian universities, especially in the late 90's, mainly due to internal policies of intellectual property with patents stimulus and an improvement in the management of academic inventions. 
Discussion concerning the protection of intellectual property is novel at the university level and has been receiving increased attention in Brazilian economics, which can be demonstrated by the improvement of laws concerning intellectual property protection, training forums and support centers for innovation. Despite the high level of scientific and technical experience of Brazilian researchers, innovation capacity at the universities and research institutes is blocked by the demanding bureaucracy. Moreover, the incipient number of patent applications by the universities and research institutes in Brazil suggested a lack of intellectual property protection at the academic level. The existence of a "publishor-perish" systems associated with the graduate programs funded by the Coordenação de Aperfeiçoamento de Pessoal de Nivel Superior (CAPES) and Conselho Nacional de Pesquisa (CNPq), contributed negatively to this situation (Scholze 2001). In addition, there was a lack of i) information regarding both free and private access patent databases, ii) researcher training for utilization of the databases, and iii) knowledge regarding the patentability requirements, especially with reference to patents, which have novelties and/or innovations, related to life sciences (Moreira et al. 2006).

One of the main consequences resulting from the low level of knowledge of the industrial property system by the universities and research institutions in Brazil is the lack of access to the technological information contained in these comprehensive databases (Nunes and Oliveira 2007). Since 70\% of all the information contained in patent documents cannot be found in other media, the ability of researchers to navigate these databases is of utmost importance in the context of technological innovation (Haase et al. 2005).

Majority of the supporting agencies have yet to consider paper publication as the preponderant indicator for the researcher evaluation, which interferes with the patenting by the academic institutions (Emerick 2001). Additionally, some institutions that support research now note the existence of patents in the researcher curriculum in their evaluations for grant funding. The protectionof generated knowledge in the universities and research institutes in the form of patents allows for the improvement of research through allocation of resources from the royalties. Through patent licensing, the knowledge generated in public institutions should result in benefits to the society. However, researchers at Brazilian universities still encounter many difficulties in obtaining adequate support concerning the knowledge protection (Buttow 2008). In 2008, a recent initiative by the CAPES has created a Biotechnology area to stimulate technological development and partnership between the university graduate programs and industry in order to increase the Brazilian competence for patent generation of products and innovations.

\section{CONCLUSION}

The present study revealed the need for knowledge on practices and laws governing the intellectual property in Brazil to be disseminated within the areas related to biotechnology. The absence of a culture for knowledge protection results in the loss of a link between the academia and industry for technological knowledge transfer and, consequently, deprives the society of the potential benefits. Moreover, much of the technological information available worldwide is released only through patent documents, and, therefore, the ability to search databases becomes indispensable for country development.

\section{ACKNOWLEDGMENTS}

The authors will thanks to the Conselho Nacional de Pesquisa $(\mathrm{CNPq})$, for financial support and to Msc. Mariel Marlow and Dr. André Báfica for their critical reading of the manuscript and suggestions.

\section{REFERENCES}

Barbosa DB. Pipeline: uma inconstitucionalidade patente. [Internet] 2002. [Cited 2010 Jun 15] Available from:

<http://denisbarbosa.addr.com/27.rtf>.

Bernardes AT, da Motta e Albuquerque E. Cross-over, thresholds, and interactions between science and technology: lessons for less-developed countries. Res Pol. 2003; 32: 865-885.

Boff SO. Patentes na Biotecnologia e Desenvolvimento. In Barral W e Pimentel LO. Propriedade Intelectual e Desenvolvimento. Florianópolis: Fundação Boitex. 2007, p. 253-279. 
Brisolla SN. O Projeto "Universidade e Empresa, Ciência e Tecnologia". Educação \& Sociedade. [Internet] 1996. [Cited 2010 Jun 29]. Available from: http://www.cedes.unicamp.br/revista/rev/pesq56/pesq 562.html.

Buttow ME. Patenteabilidade em Biotecnologia no Brasil: estudo de caso do Programa de pós-graduação em Biotecnologia da Universidade Federal de Santa Catarina. [Master Thesis]. Florianópolis, Brasil. Universidade Federal de Santa Catarina, 2008.

Castilho EWV. Patentes de Produtos de Origem Biológica. In Picarelli MFS, Aranha MI. Política de Patentes em Saúde Humana. São Paulo: Atlas, 2001; p. 70-88.

Cruz CHB. A universidade, a empresa e a pesquisa que o país precisa. Parcerias Estratégicas. 2000; 8: 5-30.

Emerick MC. Curso de Patentes Biotecnológicas - Dos conceitos básicos à elaboração do Pedido de Patente. CNPq - FIOCRUZ - REPICT/RT. 22-26/10/2001. Rio de Janeiro, RJ. 2001.

Fortes MHP, Lage CLS. Depósitos nacionais de patentes em biotecnologia, subclasse $\mathrm{C} 12 \mathrm{~N}$, no Brasil de 1998 a 2000. Biotemas. 2006; 19: 7-12.

Gouvea R, Kassicieh S. Using resources in R\&D policy planning: Brazil, the Amazon and biotechnology. Technol Forecast Soc Chang. 2005; 82: 535-547.

Gulo LMG, Guerrant RDS. Maiores depositantes de pedidos no Brasil, com prioridade brasileira. [Internet] 2006. [Cited 2010 Jun 15]. Available from: http://www.inpi.gov.br.

Haase H, Araújo EC, Dias J. Inovações vistas pelas Patentes: Exigências Frente às Novas Funções das Universidades. Revista Brasileira de Inovação 2005; 4: 248 .

Instituto Nacional de Propriedade Industrial (INPI). [Internet] 2006. [Cited 2010 Sep 28]. Available from: http://www.inpi.gov.br.
Moreira AC, Müller ACA, Pereira JR, Antunes AMS. Pharmaceutical patents on plant derivate materials in Brazil: policy, law and statistics. World Patent Inf. 2007; 28: 34-42.

Morel CM, Carvalheiro JR, Romero CNP, Costa EA, Buss PM. The Road to Recovery. Nature. 2007; 449: 180-182.

Nunes JS, Oliveira LG. Universidades Brasileiras Utilização do Sistema de Patentes de 2000 a 2004. [Internet] 2007. [Cited 2010 Jun 04]. Available from: http://www.inpi.gov.br.

Sapsalis E, Potterie BP, Navon R. Academic versus industry patenting: An in-depth analysis of what determines patent value. Res Pol. 2006; 35: 16311645.

Scholze SHC. Política de Patentes em Face da Pesquisa em Saúde Humana: Desafios e Perspectivas no Brasil. In Picarelli MFS, Aranha MI. Política de Patentes em Saúde Humana. São Paulo: 2001; p. 48-50.

Silva LB. É possível negociar a Biodiversidade? Conhecimentos Tradicionais, Propriedade Intelectual e Biopirataria. In: Barral W, Pimentel LO. Propriedade Intelectual e Desenvolvimento. Florianópolis, Brasil. Fundação Boiteaux. 2007. p. 299-328.

Vasconcellos AG. Propriedade Intelectual dos conhecimentos associados à biodiversidade, com ênfase nos derivados de plantas medicinais - desafio para inovação biotecnológica no Brasil. [PhD Thesis]. Rio de Janeiro, Brasil: Universidade Federal do Rio de Janeiro; 2003.
Received: October 15, 2010; Revised: July 13, 2011; Accepted: December 12, 2011. 